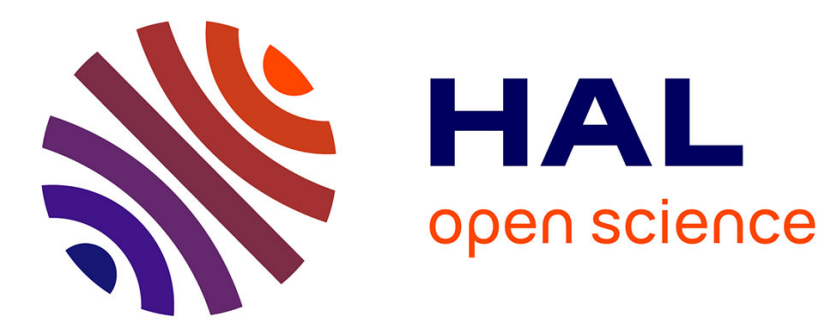

\title{
Low Temperature Sintered Ni-Zn-Cu Ferrite
}

T. Nakamura, Y. Okano

\section{To cite this version:}

T. Nakamura, Y. Okano. Low Temperature Sintered Ni-Zn-Cu Ferrite. Journal de Physique IV Proceedings, 1997, 07 (C1), pp.C1-91-C1-92. 10.1051/jp4:1997126 . jpa-00254968

\section{HAL Id: jpa-00254968 https://hal.science/jpa-00254968}

Submitted on 1 Jan 1997

HAL is a multi-disciplinary open access archive for the deposit and dissemination of scientific research documents, whether they are published or not. The documents may come from teaching and research institutions in France or abroad, or from public or private research centers.
L'archive ouverte pluridisciplinaire HAL, est destinée au dépôt et à la diffusion de documents scientifiques de niveau recherche, publiés ou non, émanant des établissements d'enseignement et de recherche français ou étrangers, des laboratoires publics ou privés. 


\title{
Low Temperature Sintered Ni-Zn-Cu Ferrite
}

\author{
T. Nakamura and Y. Okano
}

R\&D Division, Toda Kogyo Corporation, 4-1-2 Funairi-minami, Naka-ku, Hiroshima 730, Japan

\begin{abstract}
The low temperature sintering of $\mathrm{Ni}-\mathrm{Zn}-\mathrm{Cu}$ ferrite has been investigated by usual ceramic technique. The sintering density and the permeability of the sintered ferrite were strongly affected by the size of the starting oxide powders and the pre-sintering temperature. It was most effective to utilize fine particles of iron oxide and to calcine at about $800^{\circ} \mathrm{C}$ for the preparation of high permeability ferrite. The sintered ferrite with a density greater than $4.5 \mathrm{~g} / \mathrm{cc}$ and the permeability at $10 \mathrm{MHz}$ greater than 200 was obtained at relative low sintering temperature (about $900^{\circ} \mathrm{C}$ ). This condition is stitable for multilayer chip inductor application.
\end{abstract}

\section{INTRODUCTION}

Recently, the surface mounting devices have been rapidly developed using a multilayer chip inductor[1]. This chip inductor is produced by coating ferrite and electrical pastes alternately and by co-firing. Since Ag is usually used as an electrode material, high temperature co-firing causes unexpected lowering of the inductance due to the interfacial diffusion between the ferrite and the Ag electrode. The interfacial diffusion can be suppressed by co-firing at a temperature lower than the melting point of $\mathrm{Ag}\left(960^{\circ} \mathrm{C}\right)$. Therefore, low-temperature sintering of ferrite is strongly demanded.

In the present work, we have studied the low-temperature sintering of $\mathrm{Ni}-\mathrm{Zn}$-Cu ferrite and clarified the relations between preparation conditions (calcination temperature and particle size of starting materials) and some properties of the sintered ferrite (sintering density and permeability). We have also discussed the permeability variation with the sintering density from the view point of the spin and domain wall contributions.

\section{EXPERIMENTS}

Different size of $\mathrm{Fe}_{2} \mathrm{O}_{3}, \mathrm{NiO}$ and $\mathrm{ZnO}$ particles were used for the preparation of $\mathrm{Ni}-\mathrm{Zn}-\mathrm{Cu}$ ferrite sintered ceramics : calcination and sintering temperature were changed to find the optimum condition for low-temperature ferrite sintering. $\alpha$ $\mathrm{Fe}_{2} \mathrm{O}_{3}$ coarse particles (the average diameter of $0.15 \mathrm{~mm}$ ) were synthesized by the oxidation of $\mathrm{Fe}_{3} \mathrm{O}_{4}$ particles at $800^{\circ} \mathrm{C}$. The $\mathrm{Fe}_{3} \mathrm{O}_{4}$ particles were precipitated by aerial oxidation of alkaline $\mathrm{Fe}(\mathrm{OH})_{2}$ suspension at $80^{\circ} \mathrm{C} . \gamma-\mathrm{Fe}_{2} \mathrm{O}_{3}$ fine particles (the average diameter of $0.03 \mathrm{~mm}$ ) were prepared by thermal decomposition of ferrous oxalate at $400^{\circ} \mathrm{C}$ in air. The ferrous oxalate particles were precipitated by mixing of ferrous sulfate and oxalic acid aqueous solutious at $50^{\circ} \mathrm{C}$. Industrial grade particles of $\mathrm{Ni}$ oxide, $\mathrm{Zn}$ oxide and $\mathrm{Cu}$ oxide were used as the coarse particles (their average diameters were $0.5,0.18$ and $0.4 \mathrm{~mm}$. respectively). And fine particles of $\mathrm{Ni}$ oxide and $\mathrm{Zn}$ oxide were also synthesized by thermal decomposition of $\mathrm{Ni}-$ and $\mathrm{Zn}$ oxalate at $400^{\circ} \mathrm{C}$ in air, the average diameter of which were 0.04 and $0.02 \mathrm{~mm}$, respectively.

$\mathrm{Ni}-\mathrm{Zn}-\mathrm{Cu}$ ferrite ceramics were synthesized by usual ceramic technique (double sintering method). Starting powders $\mathrm{Fe}_{2} \mathrm{O}_{3}$. NiO, $\mathrm{ZnO}$ and $\mathrm{CuO}$ were mixed together with wet attrition milling. Their molar ratio was adjusted to the composition of $\mathrm{Ni}_{0.26} \mathrm{Zn}_{0.52} \mathrm{Cu}_{0.25} \mathrm{Fe}_{1.97} \mathrm{O}_{4}$. The mixtures were calcined in air at several temperature ranging from 750 to $850^{\circ} \mathrm{C}$ for four hours, and re-ground by wet ball milling. The obtained ferrite powders were mixed with an appropriated anount of poly-vinyl-alcohol as a binder. subjected to the press compacting (plate with the diameter of $50 \mathrm{~mm}$ and the thickness of about $5 \mathrm{~mm}$ ) and sintered in air at temperature range from 850 to $920^{\circ} \mathrm{C}$ for four hours. 


\section{RESULTS AND DISCUSSION}

First. the calcination temperature was fixed at $800{ }^{\circ} \mathrm{C}$ in order to examine the effects of the starting materials. Both the sintering density and the permeability increased with a increase of the sintering temperature for each set of the starting materials. It was found that using the fine particles as the starting materials led to the greater sintering density and the greater permeability at the same sintering temperature. Especially, using fine iron oxide particles was most effective to obtaint. the sintered ferrite with high sintering density and high permeability. Small starting oxide particles are transformed into smaller ferrite particles during the calcination process. These smaller ferrite particles have larger surface area and larger free energy. Since the surface free energy is considered to be a driving force in the sintering process, the smaller ferrite particles tend to be well sintered. Therefore, the use of fine oxide particles as the starting materials is effective in preparing high density sintered ferrite through low-temperature sintering .

Next, the starting materials and the sintering temperature were fixed and then we examined the effect of the calcination temperature. The sintering density remained almost constant at the calcination temperature below $800^{\circ} \mathrm{C}$, and it decreased when the calcination temperature exceeded $800^{\circ} \mathrm{C}$. The particle size of the calcined ferrite increases when the calcination temperature is raised. Accordingly, large thermal energy is required to sinter the particles : low-temperature sintering is considered to be difficult. On the other hand. the permeability had a maximum value at about $8000^{\circ} \mathrm{C}$ of the calcination temperature. These results indicate there exists an optimum calcination temperature to obtain high permeability ferrite ceramics.

From these results, both the utilization of the fine iron oxide particles as the starting materials and the appropriate temperature calcination produces the sintered ferrite with high density and high permeability. The sintered ferrite which was synthesized by use of $\gamma-\mathrm{Fe}_{2} \mathrm{O}_{3}$, calcination at $800^{\circ} \mathrm{C}$ and sintering at $900^{\circ} \mathrm{C}$ had the sintering density of about $4.6 \mathrm{~g} / \mathrm{cc}$ and the real permeability about 200 at $10 \mathrm{MHz}$ and approximately 30 at $100 \mathrm{MHz}$.

The preparation conditions have a large effect on the permeability. since these ferrites are in polycrystalline form. In order to clarify the factors affecting the permeability, the relationship between the sintering density and the permeability was examined. The permeability value at $100 \mathrm{MHz}$ increased with a increase of the sintering density and saturated at about $4.5 \mathrm{~g} / \mathrm{cc}$. In general. the permeability is related to two different magnetizing mechanisms : the spin rotational magnetizing and the domain wall motion. It is known that the complex permeability of sintered ferrite in $100 \mathrm{MHz}$ region is almost determined by the spin rotation magnetizing mechanism[2] and that the spin rotational component of the permeability depends only on the ferrite volume loading, i.e. the sintering density[3.4]. Therefore, the permeability in $100 \mathrm{MHz}$ region can be controlled by the sintering density.

Roughly speaking. the permeability at $10 \mathrm{MHz}$ also had the same trend and increased with the sintering density: However. the permeability values at $10 \mathrm{MHz}$ were spread over a wide range owing to the difference of some conditions : there are highly sintered ferrite ceramics with low permeability. While, in $100 \mathrm{MHz}$ region, the permeability can be described only with the spin rotational component, the contribution of the domain wall motion cannot be negligible in $10 \mathrm{MH} / \mathrm{region}$. The SEM observation for the fracture surface of the sintered ferrites which had almost the same sintering density indicated that the growth of the ferrite grain resulted in the greater permeability value at $10 \mathrm{MHz}$. Globus suggested that the domain wall motion was affected by the grain size and enhanced with the increase of the grain size[5]. Accordingly. it is necessary to increase the sintering density and the ferrite grain size for high permeability in $10 \mathrm{MHz}$ region. Although low-temperature calcination produces small ferrite particles which has high sintering ability even at relative low temperature. resulting in the ferrite ceramics with high sintering density, the grain growth of the ferrite particles is not sufficient. This is a reason why there exists the optimum calcination temperature for high permeability ferrite ceramics.

\section{CONCLUSIONS}

The sintering density and the complex permeability of Ni-Zn-Cu ferrite ceramics can be controlled by the particle size of the starting oxide materials and the calcination temperature. By using the starting oxide materials with fine particle size and the calcination at an appropriate temperature, the ferrite particles with easy sintering ability can be obtained and they provide the preparation of the sintered ferrite with high density and high permeability in the relative low-temperature sintering

\section{References}

[1] T.Nomura and M.Takaya : HYBRIDS 3,15(1987).

[2] Y.Naito : Proc.Int.Conf.Ferrite (1970)558.

[3] T. Nakamura. S. Yamamoto. T.Tsutaoka. S.Shimizu. E.Hankui and K.Hatakeyama : Proc.Int.Conf.Ferritc (1992)1298.

[4] T.Nakamura. T.Tsutaoka and K.Hatakeyama : J. Magn. Magn. Mater. 138. 319(1994).

[5] A.Globus : J.Phys.Suppl.C1(Proc.ICF-3)(1977)1. 